\title{
The Formation of Traditional Music and Regional Pop Music Community in Popular Social Media
}

\author{
SHAFA'ATUSSARA SILAHUDIN \\ University of Malaya
}

\begin{abstract}
Traditional music and regional pop music are two music genres in Pahang. Both music genres provide the cultural meanings to the Pahang people. They have shared similar characteristics consisting of traditional elements inherited from the past. Quatrains of pantun and Malay traditional proverbs are adopted as sung texts in both music genres. Interestingly, the implementation of Pahang spoken language (Pahang dialect), one of the Malay dialects in Peninsula Malaysia, is an additional characteristic of regional pop music. Both music genres incorporate tradition and modern elements of tempo, melody and music structure. In both music genres, the combinations of modern and traditional musical instruments are used. Music practitioners, Roslan Madun and vocal group Anok Semantan represent traditional and regional pop, respectively. To investigate community formation through the genres, three methodological components are used: participant-observation, interviewing, and textual analysis. The findings suggest that community in traditional music (in this regard, syair songs) is formed through syair concert, and the formation of virtual community in media social of Facebook as continuity of the concert community. Regional pop music, on the other hand, forms the community on the popular music web of YouTube. The findings also expose different in attitudes, motivations and practices between traditional and regional pop communities.
\end{abstract}

Keywords: Traditional music, regional pop music, Roslan Madun, Anok Semantan, community formation.

\section{INTRODUCTION}

The purpose of this paper is to discuss two music genres: traditional and Pahang regional pop, and how the genres contribute to the formation of community on popular social media of Facebook and YouTube. The Internet was invented in 1969 and is defined as 'information high-way' (Campbell, Martin \& Fabos, 2007, p.41). Facebook is one of the Internet platforms, and the most commonly visited website worldwide. Launched in February 2004, owned and operated by Facebook Incorporated, Facebook is the largest of social networking website with approximately 1.79 billion of active users throughout the world (Facebook Statistic, 2016). Activities on Facebook predict a wide range of personal attributes of users (Kosinski et al., 2013). On Facebook, individuals are becoming more and more connected and spending significant amounts of time engaging in this Internet-based social network. YouTube, a video-sharing website founded in February 2005, has become the fourth most visited website in Malaysia (Top Sites in Malaysia, Alexa.com, n. d.) - behind Facebook, Twitter, and Google.

On the platform of YouTube, users upload copies of professional content, in other word, user-copied content (Ding et al., 2011). It allows the content including local music to be available to a global audience (Yu \& Schroeder, 2018). In Liikkanen and Salovaara's (2015) work, they identify watching videos has become one of the most popular activities in the Internet. They consider topics on online music listening and watching videos with specific focus on users' interactions and engagement patterns with recorded music. Yu and 
Schroeder (2018) give a way on how I could examine digital communications among online music users by taking a case study of distribution of Chinese music on YouTube.

Traditional music has allegedly been considered a type of songs inherited from the past. The term 'traditional' refers to established musical traditions. The music can consist of vocals to instrumental accompaniment, and instrumental dance music. In the context of Pahang villages, traditional music can be divided into five sub-categories: 1) lagu tradisi rakyat (traditional-folk song, 2) lagu rakyat baru (new-folk song), 3) lagu puisi tradisional (traditional poetry song), 4) lagu tarian (dance song), and 5) lagu puisi kontemporari (contemporary poetry song). The frequent affiliation of traditional music with custom and ritual ensures of the continuity with the past. The lyrics of traditional songs are "of literary context that is an integral part of the music composition" (Proehoeman, 2012, p.102).

Traditional songs continue to appear today as they are spurred by the people's attempt to return to the old ways or traditional ways. Song community (including performers) discovers satisfaction in traditional songs that provide historical links to the past. People especially the elders believe that it is their obligation to practice the past songs in appropriate song events as continuation from the previous periods. They understand their obligation to survive and thrive their musical heritage. Traditional songs serve a wide variety of objectives. Nostalgia, through different kinds of vocal forms provides a powerful tool for a community trying to understand their present existence. Also, singers and music practitioners with their abilities have made traditional songs remembered for a long term. They reinvent music tradition to preserve their heritage. Traditional songs are performed within the context of the present song events. Some songs can only be sung in specific contexts, while others in an array of contexts. In brief, traditional songs have indeed become a part of Malay traditions. They are remembered because of what they have done to the community. A number of strategies have been employed towards the creation of new performance scopes.

Regional pop (pop daerah) is one of music genres in Pahang that its first emergence could be traced as early as the late 1970s, the period of the technological, economic and organizational developments in music industry. Borrowing the definition from Wallach, regional music is "a catch-all category that includes every style of music sung in regional languages, from the most westernized pop to the most stable indigenous performance tradition" (Wallach, 2008, p.34). 'Regional' in this context is classified as the implementation of Pahang spoken language that is of Pahang dialect in song lyrics. Pahang dialect is one of the regional dialects in Malaysia. Pahang dialect is somewhat a bit different from other Malay dialects in the west coast of Peninsula Malaysia (Nik Safiah et al., 1986). Pahang dialect forms a recognizable subgroup with two other states in the east coast, Terengganu and Kelantan (Collins, 1989). There are minor dialects boundaries between the communities in the three aforementioned states. The location of three main rivers as seen in Map 1 "indicates the apparent factors which link these dialects to each other, despite the great distances separating them" (Collins, 1989, p.254). Meanwhile Asmah Omar (1976) classifies Kelantan, Terengganu, and Pahang into separate subgroups of Malay, although she notes that Pahang is a transitional area linking Terengganu Malay to Johor Malay in the south. Asmah Omar in 1985, however, revised her classification, placing Kelantan, Terengganu, and Pahang in a single subgroup. 


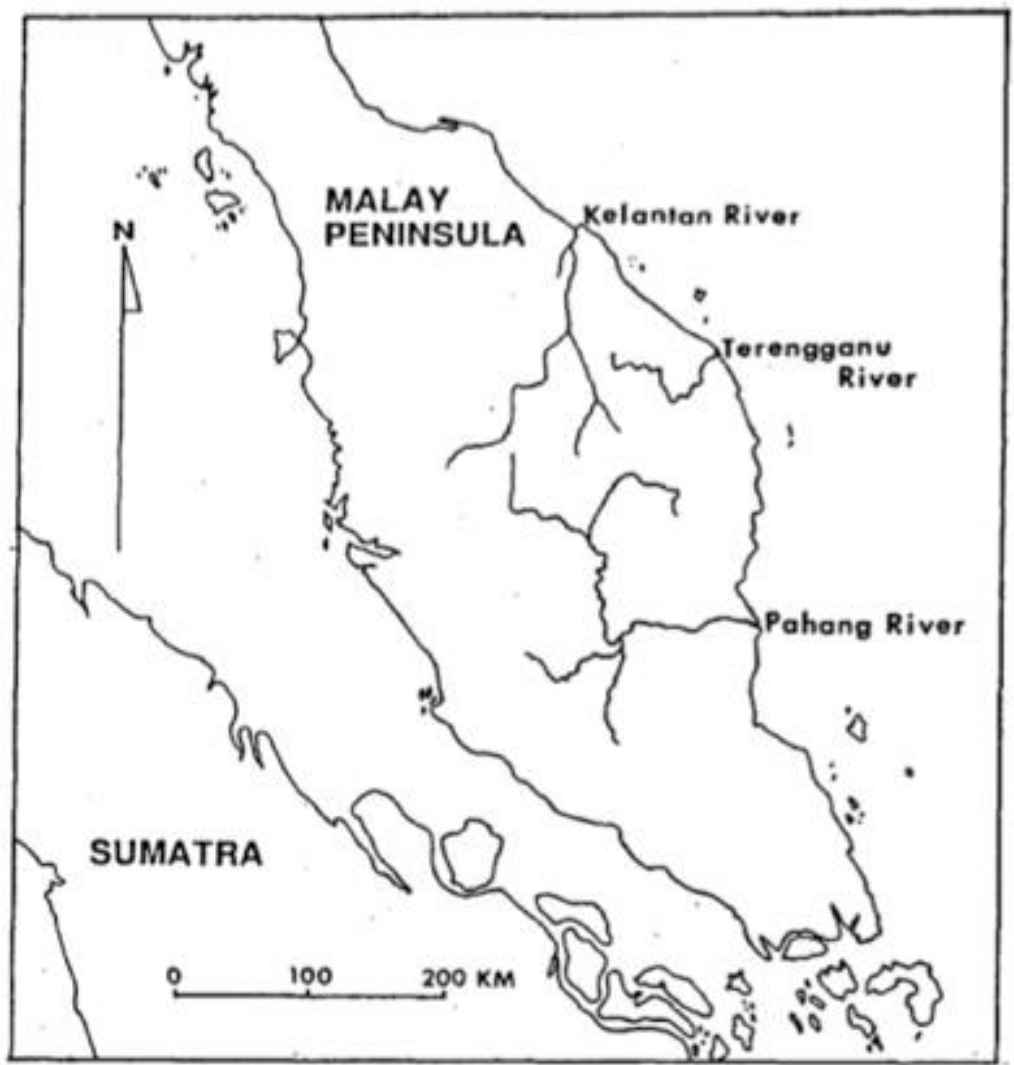

Map 1: The major rivers of the east coast of the Peninsula Malaysia (source: Collins, 1989)

In a conversation with the wife of former Menteri Besar of Pahang (head of government of the state of Pahang), Junaidi Kassim a school teacher, the Pahang dialect is unique according to the location of every district with the Pahang River. The community in the upper area has a faster speech compared to the downstream area influenced by economics and living conditions. The community in the upper area needs to speak fast due to the fast stream of the river in the area. In her metaphorical explanation, Junaidi said that the river is the main communication route within the community. Slow speech will make them 'slow' both in delivering a meaning and gain a living because they will be 'abandoned' by the fast stream (Junaidi Kassim, personal communication, 23 January 2019).

Pahang regional pop includes genres of which are innovative and adopt elements of global music. It is in other words a term refers to a mixture of traditional or verbal arts (pantun verses) and national/foreign musical influences with song lyrics in the Pahang dialect written by local songwriters and sung by local singers. Regional pop indicates that there is something new and modern in its features. Pahang regional pop consents modernity in a local context without losing local colors. Aesthetic aspects including rhythm, melody, tempo, and formal structure of regional pop music differ from traditional music.

\section{LITERATURE REVIEW}

Several works deal with Pahang music. Matusky (1985) in her work entitled "An introduction to the major instruments and forms of traditional Malay music" discussed a vocal form of storytelling (penglipur lara), an important oral tradition among the Malays in Pahang. With it, folk music tradition had been developed to accompany the telling of folk tales. There were five components in storytelling: the use of stylized language, singing, chanting, musical 
accompaniment and drama. The two musical instruments that accompany the storytelling in Pahang were rebab (Malay viol) and rebana (frame drum). Besides storytelling, a Muslim devotional genre of zikir was also discussed. It involved Arabic texts from Kitab Barzanji (Islamic book to praise of the Prophet Muhammad) sung by groups of men that was accompanied by rebana besar (big frame drum). In 2003, Pejabat Kebudayaan dan Kesenian Negeri Pahang (Pahang Cultural and Arts Department) had published a published work entitled "Koleksi pengenalan tarian dan muzik tradisional Negeri Pahang" ("The collection of introduction to dances and traditional music in Pahang") to introduce fourteen types of dance-music in Pahang. I consider this work as a compilation of dance-music with only brief description of each song. Even though this work is non-ethnographic, it has, however, contributed to my knowledge with songs including sewang by Orang Asli Jah Hut and Orang Asli Temiar, anak indung by Malays of Ulu Tembeling (upstream of the river), song titles amongst Orang Asli Semelai, dikir rebana by Malays from Bangau Tanjung village in Temerloh, and gamelan songs by cultural group in the district of Pekan, Pahang.

To add, Aripin Said (1997) had written wrote two prominent works on Pahang musical culture. In his book "Lagu-Lagu tradisional rakyat Pahang" ("Pahang traditional folk songs"), Aripin Said had provided a number of songs he collected through his ethnographic work within six years from 1977 until 1983. Throughout his research, Aripin Said had centered his station in several villages along the Pahang River. Amongst the songs that had been discussed in this book include ugam mayang (heal song by the help of seven supernatural princesses), dikir rebana (religious songs accompanied by frame drum), jampi serapah (incantation) and folklore songs including Indung-Indung (Mother, Mother), Puteri Walinong Sari (Princess of Walinong Sari), Burung Kenek-Kenek (name of a well-known tune with extempore verses to the refrained pesan dato' nenek), Lagu Orang Muda (Tune for the Young), Anak Ayam Turun Sepuluh (a song sung to children), and berdah (an Arabic song from Islamic book of Kitab Barzanji). The use of Kitab Barzanji as the singing text is still significant today in amateur music genres and will be explored later in chapter five of this book. After seven years, in 2004 "Nyanyian rakyat khazanah bangsa yang hilang" ("The lost of folk singing as a national treasure") Aripin Said enlightened briefly about singing tradition called penglipur lara (consolation song). Historically, this tradition was popular among the Malays in villages and was performed with the accompaniment of several instruments including frame drum, a one-string rebab (Malay viol), and serunai (clarinet of wood with a bell-shaped mouth). In this work, he examined two leading song categories based on targeted audiences: first, songs for children, and second, songs for adults. The forms of song studied are various; some would use stanzas of pantun, others in a form of unstructured or free poetry. Several examples are included in this work including extended narrative songs entitled Dayang Keknong, Burung Agut, and Anak Raja Bugis; children songs: Tebang Tebu, Sapu Rengit, and Pak Sang Bagak; and labor songs: Siul Kalui, Tepuk Daun, and Hitam Manis.

However, none of them have described in regards with how community is formed through music. These works could probably be used as a guide for readers to learn briefly about the musical culture of Pahang. 


\section{a. Participant-Observation}

\section{METHODOLOGY}

Some information included in this article comes from personal experience and participantobservation over a series of field studies (2013-2018). As a traditional singer, I have involved in several cultural singing performances with Pahang traditional singers. In this way, I could enhance my understanding of musical cultures in Pahang. While conducting my field study, I was given the opportunity to learn traditional Malay poetry. Besides contributed in an array of singing performance along with Pahang singers, I recorded all singing performances in the events that I had attended. With permission, I hanged out with singers/musicians, patrons, and audience with a hope to arrive at normative patterns of musical and social behaviors that characterize music events of a particular type. An analysis of musical events allows me to understand how singers/musicians involve in performance and why they do so in this particular way.

\section{b. Interviewing}

I collected singing data for this study in a primary form of oral interview with performers. Interviews were conducted in environments selected by them including their homes, coffee shops, music practice areas, and at shows. No formulated question is prepared before the interview sessions, only open discussion with them in relation with historical development of singing culture in Pahang, and their points of view about related topic. Impromptu interview sessions were conducted mainly after cultural events were carried out. Conversations with performers continue through electronic communications including email and text messaging on specific matters while assessing field notes and video recordings. It is to make sure that my interpretation in viewing recorded performances is in line with their presumption. I would also make sure the performers/informants willing to share information without compulsion. All interviewed data were recorded using a recorder device, documented in video recordings, transcribed when appropriate as well as transliterated for further reference.

\section{c. Textual Analysis}

Two types of textual analysis were used in this study: language texts, and audiovisual texts recorded by myself. For language texts, I referred to a number of published works from university libraries, online books, websites and social media of Facebook and YouTube. Language texts also included transcribed texts from though, speech and singing performances collected from the field. A number of audiovisual texts were used in this study. I referred to some video recordings captured by myself and by other individuals (by approval). Music albums were also considered in this study. I learned traditional and regional pop songs from the performers' music albums and interpreted the song lyrics. Equally important, I also analyzed music videos uploaded by fans on YouTube.

\section{RESULT AND DISCUSSION}

\section{a. $\quad$ Roslan Madun and Community Formation Through Traditional Music}

Roslan Madun (Figure 1) was born in Temerloh, Pahang in 1952. In his teenage years, Roslan was exposed into stage performance through a traditional theatre of bangsawan (a type of Malay popular commercial theatre which combined Malay, Western, Indian, Chinese, Javanese and Middle Eastern elements) in the village. At that time, he became the youngest 
actor in bangsawan production. In his first attempt in music, Roslan received rejection from his father who was a religious teacher and practitioner of Islamic song of dikir in the village. In regards with singing, Roslan clarified that pop yeh yeh (a popular music in the 1960s) was his first music genre he tried to sing. His attachment to pop yeh yeh was not long; he then changed it to traditional music. Roslan began to sing traditional songs professionally since the 1980s. The most important person in the development of Roslan as traditional music singer was Aripin Said. The latter used to be Roslan's performing teacher.

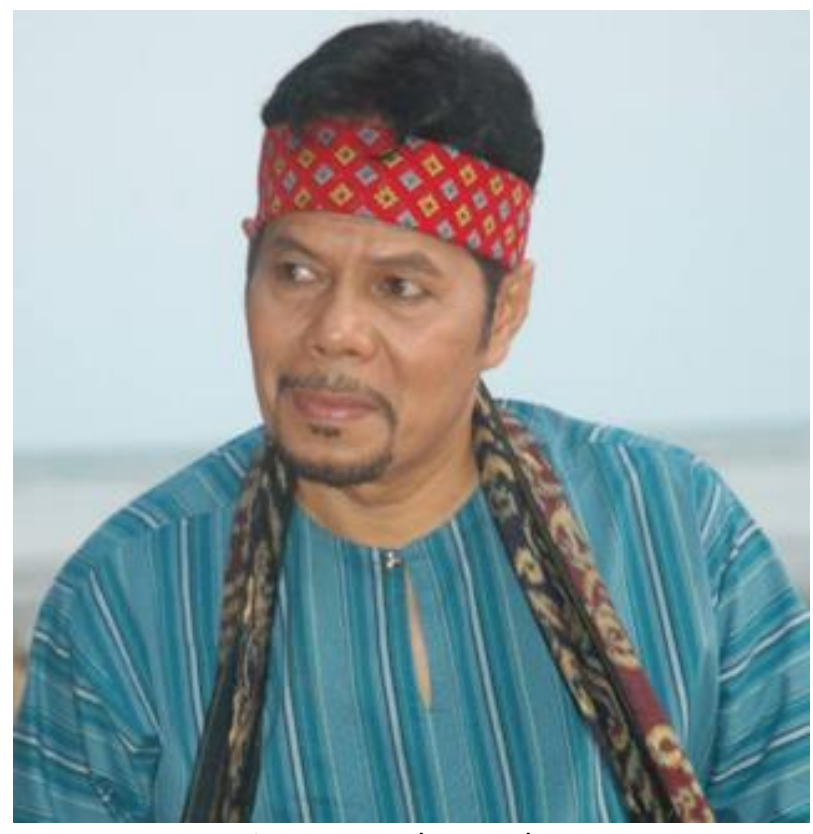

Figure 1: Roslan Madun

Roslan's music journey is not limited within Pahang. In early 1980s, he moved to Kuala Lumpur to receive a job offer as jounalist in one of the publishing companies in Malaysia. His passion and enthusiasm in traditional music had never stopped. He continues to sing traditional songs in many kinds of song events. At that point of time, he earned a living professionally as a journalist as well as traditional music singer. After about twenty years in Kuala Lumpur, in the 2000s, he returned to Pahang. Collaborated with local friends, Roslan established an organization namely Anggun Performing Arts. This organization aims to intensify artistic- and cultural-based programs in Pahang. Between 2001 until 2006, Anggun Performing Arts cooperated with the state government to host several music festivals and theatrical performances held mainly in the vicinity of Temerloh. Within more than thirty years of involvement as traditional music singer, Roslan involved in hundreds of song events in local and national levels. Besides that, Roslan was one of regional musicians on national cultural missions to several countries including Korea, Japan, and Cambodia, not to mention the neighboring countries of Indonesia, Singapore and Brunei.

Roslan is usually affiliated with two out of five sub-categories of traditional music: lagu rakyat baru (new-folk song), and traditional poetry songs (syair, nazam, gurindam, and seloka). He has repertoires of more than eighty songs. By now, Roslan has more than sixteen albums. Roslan has self-financed most of the production of his music albums. He rented recording studios under several different independent recording companies located in Pahang, Kuala Lumpur and Melaka. Synthesizer keyboard is a prominent music instrument he used in his albums. Malm and Wallis in their study of patterns of change in the music 
industries throughout several countries found that synthesizers allowed for the production of new sounds that traditional instruments have not produced (Malm \& Wallis, 1984). Besides synthesizer keyboard, the sounds of bamboo flute and frame drum are also included. The repertoires in Roslan's music albums have been used as teaching materials in educational institutions (schools and universities).

As seen in Figure 2, visual images on compact disc covers suggest the packaging of the repertory. Each illustration on the cover personifies the content of songs. Mostly, half the number of albums illustrates Roslan as the main figure on the covers. On the album 1, a photograph of the present ruler of Pahang His Royal Highness Sultan Ahmad Syah is used. Besides that, Roslan displays Pahang-born Tun Abdul Razak, the then prime minister of Malaysia governed the country from 1970 to 1976, to commemorate the latter's devotion to the country on one of his album covers (the cover of music album is not attached here). According to Roslan, the significance of these two important figures on his album covers is to emphasize the values of tradition and development of Pahang. These two important figures are significant to the Pahang people. The photograph of Sultan Ahmad Shah signifies sovereignty and wealth of the Malay custom. Meanwhile, the photograph of Tun Abdul Razak known as the Father of Development of Malaysia indicates the state's economy growth under his governance. The Pahang people have had benefited in terms of opening new areas for plantations and a new economic policy (Dasar Ekonomi Baru) for the development of the Malays.

In album 2, there is an image of a villager rowing a small boat (sampan) in the Pahang River. Together with this image is a citation that says "Patin Temerloh". Patin is freshwater catfish that inhabit Pahang River. Temerloh has been entitled as the town of patin (bandar ikan patin). During the course of my field research in 2014, I could see many templates where each of it has a saying "Temerloh Bandar Ikan Patin" (Temerloh the City of Catfish) pasted on every pillar along the main roads in town. Thus, the Pahang River is another influential gesture appeared on Roslan's album cover that reflects local identity. On the album 3, Roslan displays several other figures on his album covers. Roslan also considers the view of village background justifies his music. Opened field ground, temporary shelter (pondok), swamp area, and Pahang River are among the nature views displayed on his album covers. On the album 4, Roslan exposes different styles of traditional attires of baju Melayu or the Malay traditional blouse, and songkok (Malay male head-dress) or with a piece of cloth tied on his head. To accompany his look, traditional instrument of Pahang frame drum is included to complement the traditional look. Some album cover has floral embroidery looks as seen in album 5 and 6.

Syair becomes essential to Roslan. The Malay syair texts could be classified into a number of categories including romantic syair and historic syair. The singing of syair is monophonic and is presented in a technique of ad libitum (at one's pleasure). Syair singing, to some extent, bear a resemblance to Qur'anic cantillation (tarannum). Farmer (1965, p.1073) defines tarannum as "unpretentious psalming varied and embroidered by the singer". The tarannum is a kind of chant that refers to "a monophonic style of singing or recitative in free rhythm... used as a heightened speech-song..." (Brakeley, 1949, p.210). In a historical context, The Malay tarannum reciters obtained training from Arab experts whose tarannum recitation was based on maqamat (a system of melodic mode used in traditional Arabic music). "The call for prayers and other Islamic vocal practices are examples of which Islamic recitations must likely have tremendously influenced the melodic perception and 
aesthetic preferences among the Malays. Since Malays are Muslims by birth, they become familiar with tarannum recitations through family members and subsequently learn Islamic recitation in school and other Islamic education centers" (Meddegoda, 2016, p.48).

Roslan actively performs syair in many kinds of song events. Besides performing syair, Roslan is frequently involved in giving discourses of traditional singing demonstrations. Between 2013 and 2016, I had attended five different courses held at different institutions. The attendees were among students of primary and secondary schools, schoolteachers, and university members. Mostly in the beginning of each discourse, Roslan would introduce the introductory description of traditional poetry. It then followed by a demonstration of syair tunes by Roslan. In sum, Roslan has been recognized for mainly two types of traditional music: new-folk song, and traditional poetry song. As a recognition for his enthusiasm and sincere in traditional songs especially in syair, he has been entitled the "King of Syair" by several cultural organizations in Malaysia and Indonesia. He continues to involve in many cultural works (kerja-kerja budaya), such as promoting traditional poetry songs through singing workshops, competitions, and song events in several states in Malaysia.

The formation of community around syair could be explored in a number of ways. In this part, I aim to discuss about the 2016 syair concert in Kuala Lumpur, and how it serves as the topic among the virtual community on Facebook. With a theme Syair Merentas Benua (Syair Across the Continent), this concert featured fourteen syair reciters from five Southeast Asia countries: Malaysia, Indonesia, Brunei, Singapore and Thailand. The concert was held in the auditorium of Institute of Language and Literature in Kuala Lumpur. The presence of fourteen syair reciters from different countries clearly illustrated that there are transnational communities around syair. The concert was held as a way to commercialize syair singing in line with other popular genres. Syair fans from other regions converged in Kuala Lumpur in a purpose to attend this concert. In my perspective, such the song event encouraged the development of global syair community. In the concert, thirteen syair tunes (Sarawak, Hiasan, Tambang Bengawan, Tukutur Balam, Batu Belah, Perindu, Rawi, Burung, Kepulauan Riau, Beghondak, Selendang Delima, Pekanbaru, and Dodoi) were delivered. Modern and traditional music instruments accompanied all the syair songs. All themes in the syair texts were adapted from the prominent Malay literary work of Sejarah Melayu or known as Sulalatus Salatin composed by Tun Seri Lanang in circa 1612 (Aveling, 2002). The syair concert had successfully assembled highly respectable audiences consisting policy makers, officials, academics, teachers, school and university students, and state artists. 


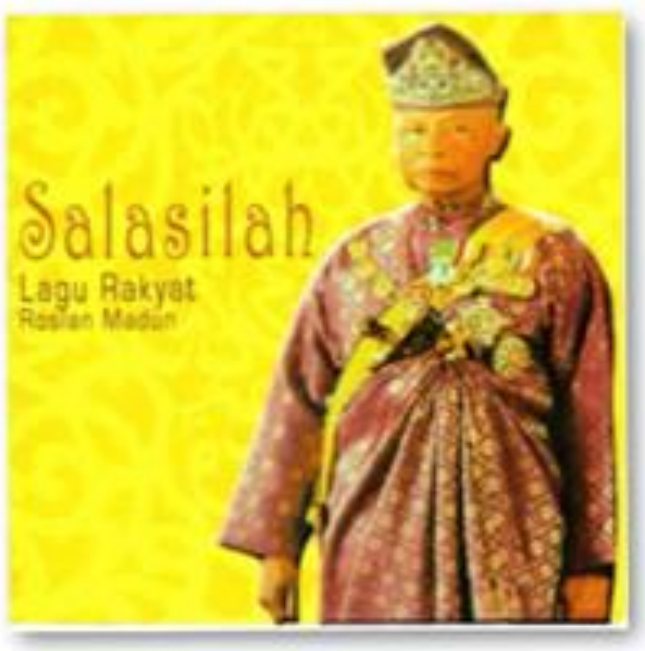

1

\section{roslan madun PUISI WARISAN}
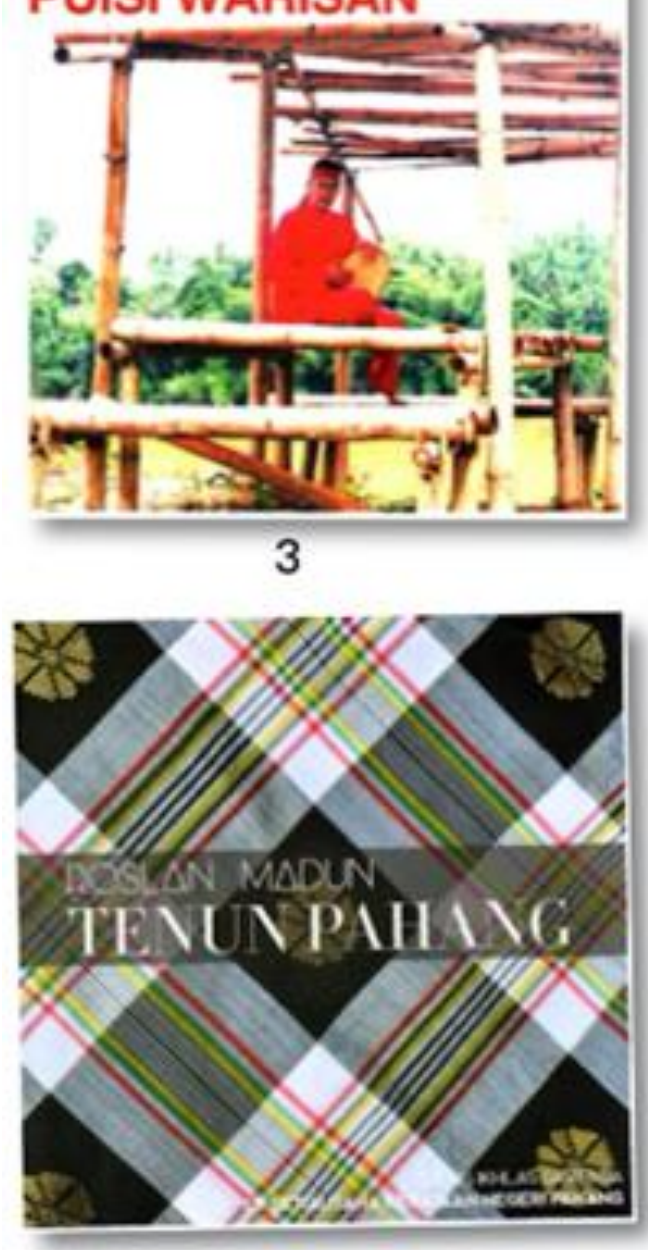

5

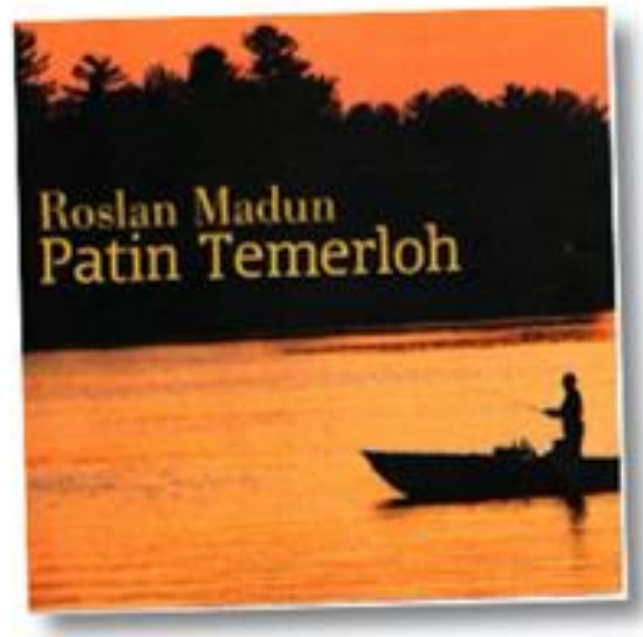

2

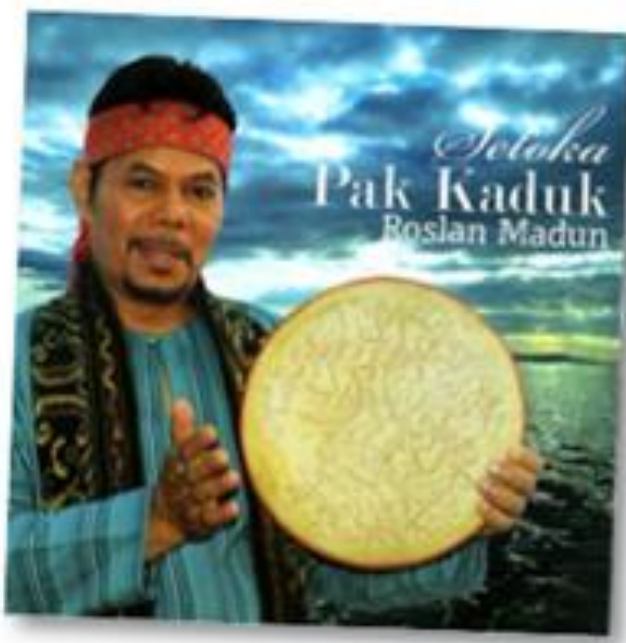

4

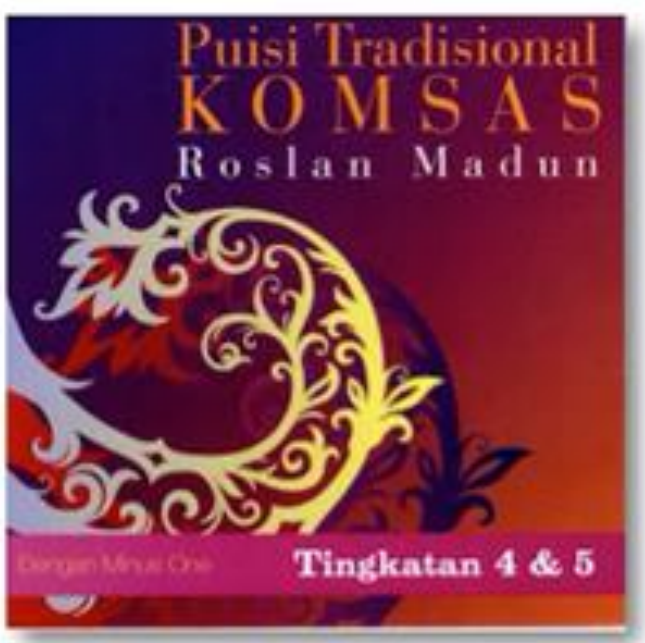

6

Figure 2: Several cover images of Roslan's music albums 
There is a continuity of the community after the concert in cyber space like Facebook. Syair has proven its potential to create a cyber community. On the social media platform like Facebook, the virtual community participates in conversation on a variety of topics. Lim, a middle-aged Chinese woman teaches Malay Language in school. Lim actively participates as online syair community on Facebook. I began to know her when she introduced herself to me after the syair concert. Lim and I continued our conversation about syair on Facebook. There, she began to learn syair singing through several videos posted by online syair community. Most of the videos have been copy-pasted from YouTube. Lim also adds that by learning syair singing, it could enrich her way of teaching Malay Language to students at school.

On her Facebook wall, Zurinah Hassan, the first female laureate from Kuala Lumpur shares her reflection about syair singing with her followers. On the 8th of July 2017, Zurinah opened a discussion on a matter of tunes and themes in syair songs. This topic had attracted her followers to participate in the conversation, and contribute to a progressive debate among them. From his note on Facebook, Amran Ibrahim from Perak who also attended the syair concert was inspired to commercialize syair singing to be more interesting. My search about him shows that Amran incorporates Arabic sound by implementing gambus (Arab musical instrument with six strings) into syair singing. As an independent, young poet, Amran actively involves in online conversations related to syair among online syair community. My investigation upon Amran's Facebook has shown that he also determined in posting such videos of syair singing performed by himself and would ask feedbacks from his Facebook followers.

A schoolteacher with a nickname Seni Jiwa on Facebook on 12th October 2016 says that after attending the syair concert, he continues to learn syair singing by attending traditional singing workshop. At the time of writing, he keeps listening to syair songs by watching several recorded videos on YouTube. YouTube channel is the main source of syair songs for him, as there is difficult and almost impossible to find recorded syair singing in markets. In sum, song event like the syair concert has provided a communicative forum through which commonalities of community are constructed and developed. The bonds of community of syair continue on popular social media of Facebook. Their active participation on Facebook in regards with syair songs and traditional Malay music culture would influence the flow of the discussions with other members. The social media of Facebook has seen as a meeting place where the syair community uses this space in the informal sense for sharing information and dialogue.

\section{b. Anok Semantan and Community Formation Through Regional Pop Music}

Anok Semantan was established in 2006 in Temerloh. 'Anok' means child, 'Semantan' is the name after the river namely Semantan River in Temerloh. The combination of these two words literally means that members of the group are of the natives of Temerloh. Anok Semantan is considered the pioneer of Pahang regional pop music. The group founder, advisor and music composer of the group is Afzainizam Ismail, aged seventy-six. In the 1970s, Afzainizam was famous for his position as a singer after he joined in national singing competition in Kuala Lumpur organized by Radio Televisyen Malaysia, the Malaysian stateowned public broadcaster. After about thirty years involved in mainstream music, in the late 1990s Afzainizam returned to Temerloh, Pahang and began to compose songs in Pahang dialect as well as set up a new group. Anok Semantan consists of five young singers: Putra, Fadlina, Zurin, Hariz and Pyan aged between twenty-nine and forty-four and based in 
Temerloh, Pahang. Interestingly, Hariz and Pyan are Afzainizam's beloved sons. It seems to me that the group of Anok Semantan is partly of musical family. For all the group members, singing is only a part of their career as they have other employment in private and government sectors. All the five singers had attended university and college for tertiary education. Indeed, they are highly educated singers.

One of the group members, Fadlina explained to me that Anok Semantan "is established with the intention of to uphold the Pahang spoken language among state communities, based on a national slogan 'Language Represents the Nation's Cultures" ("Anok Semantan ditubuhkan untuk memartabatkan bahasa pertuturan di negeri ini, berasaskan satu cogan kata nasional "Bahasa Melambangkan Budaya Bangsa") (Fadlina, personal communication, 2nd June 2016). It is useful at this point to turn to Maros's explanation of the situation in one of the disticts in Pahang. Most Malays in this district spoke variations of Kelantanese, Terengganu or standard Malay, assuming migration and language contact situations contributed to changes in the usage of Pahang dialect. The dialect is probably "in a transitional stage as the native speakers' linguistic repertoire increases with contact from other varieties of the Malay language" (Maros, 2010, p.75). Thus, from my understanding upon the remarks by Fadlina, regional pop music is an important instrument to inculcate interest among the locals to proudly speak Pahang language in their everyday discourses.

Besides employing the Pahang dialect into the lyrics, Anok Semantan also displays visual images of local element by wearing traditional fashions on music covers and in some music videos (according to the contexts of music videos). On the first music album cover (Figure 3) male singers donned different colors of baju Melayu (loosely fitting shirt with long sleeves) and worn long pants. Baju Melayu consists of two styles. The first style has a raised stiff collar known as cekak musang collar (literally fox's lease). The second does not have the cekak musang collar. Instead, the opening is hemmed with stiff stitching and ends with a small loop at the top of one side to fit a singular button. This style is known as the teluk belanga. Baju Melayu is worn with long pants with a samping (sarong-style cloth), which is wrapped around the middle of the body. This samping is a three-quarter length made of woven materials with traditional patterns. To make a loose look, the male singers either attached the samping on their shoulder or tied around waist. Meanwhile, both female singers donned baju kurung (long blouse for women). To put her appearance in more Malay-ness, Fadlina personifies her look with an opened batik cloth on her head, and a white flower worn behind her ear. The appearance of Anok Semantan in traditional fashions on the music album cover could play an important role in the promoting of the product. It is a symbol to attract regional pop music audience.

Regional pop songs were recorded on commercial compact discs composed by Afzainizam and several composers from Pahang. Among the renowned songs include Makwe Koi (My Girlfriend), Ngape Bio Semok (Why Letting the Bush Grows), Gone Gamoknye (How About It), and Meling-Meling (Indifferent). Afzainizam's recording home studio is the place for music recording as well as music practice. Regional pop songs have distinct characteristics or stylistic traits. They have both differences in rhythms (strong beats, slow and emotional) and organized melodies adapted from repertoire of traditional songs (for instance, joget style) and ornamentation. Pahang regional pop songs were played predominantly in 4/4 meter. Music instruments used in regional pop songs are guitars (sixstring and four-string bass), keyboard, and drums. The guitars provide continuous rhythm 
occasionally solo lines, the bass guitar plays the bass melody and the keyboard provides rhythm, and sometimes solos.

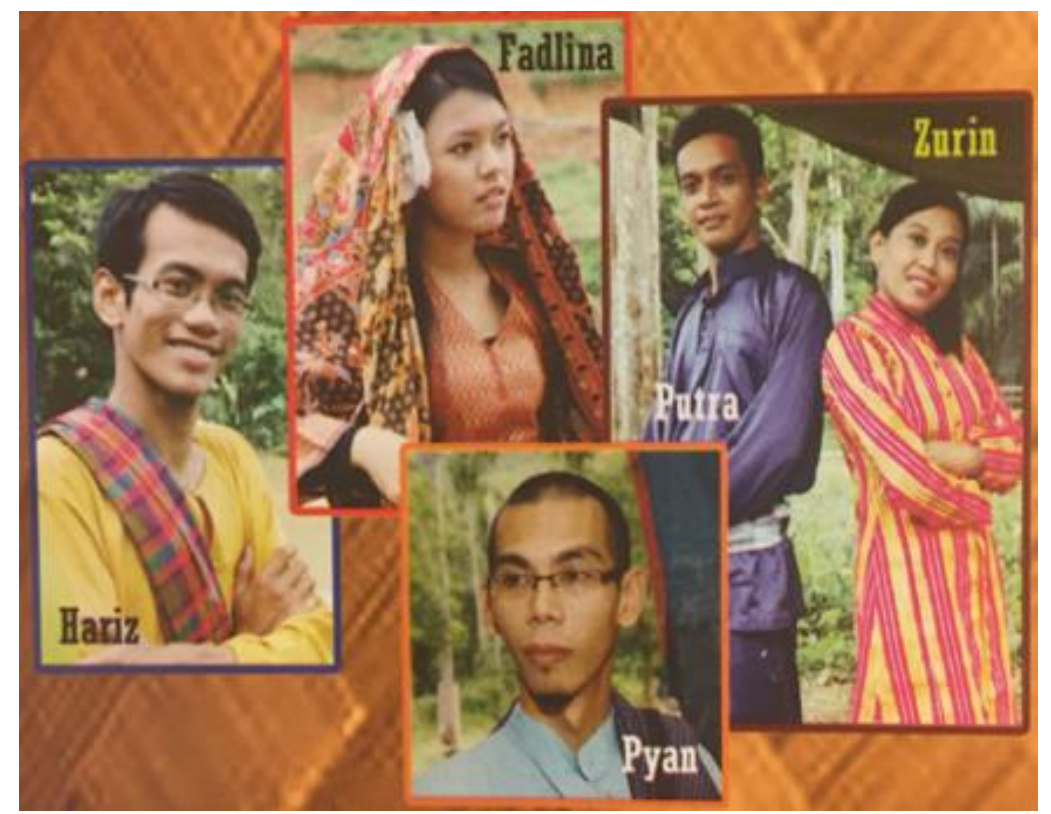

Figure 3: Anok Semantan (taken from the album cover) on traditional Malay costumes

Employing the Pahang dialect into the lyrics has given aesthetic element in the songs. The compositions are mainly simple in lyric structure, only limited numbers are in pantun verses. Besides Pahang dialect, there are nonverbal elements characterized by distinct rhythm, melody and harmony that provide the texture of the sound. Lyrics and melodies alike are fairly straightforward but meaningful and pure. Some songs are melancholy while the other portraying cheerful character, sometimes require dance. The songs encapsulate regular issues within the community. Male members mainly sing lead melodies. Harmonic texture is part of regional pop songs. The easiest place to hear it is in the background melodies sung by a vocal group. In a certain part of the song, the vocal group uses passages in vocal harmony to emphasize certain words, often the refrain or the end of a verse.

Aesthetic characteristics of regional pop songs have been translated into several music videos that consequently open for community's responses. In this part, I looked further on several music videos. All music videos were recorded in the backgrounds of Temerloh demonstrated traditional and modern elements. As for a sense of traditional, music videos were recorded in a background of landscapes of riverine village and village life styles (among the village lifestyles promoted in the music videos include bathing in the swamp, kids playing hide and seek game, chasing chicks, and fishing in the pond), abandoned old house, Pahang River, and a traditional market of Pekan Sehari. Meanwhile, to visualize contemporary or modern, some were recorded in trade building areas, and new places of attraction including parks around Temerloh (Kenangan Garden, Kubang Gajah Square, and Temerloh Lake Park). Both traditional and modern elements are of collective memories of the community.

As seen in Figure 4, the music video was recorded in the background of abandoned old house in the sense to display traditional setting. This is somehow contradicting with the image and fashion on the singers that simply symbolize modern elements. Male singers 
appeared in Western-style collar shirts with jeans, meanwhile, female singers wore modernstyle Muslim headscarves, modern-style dresses and trousers.

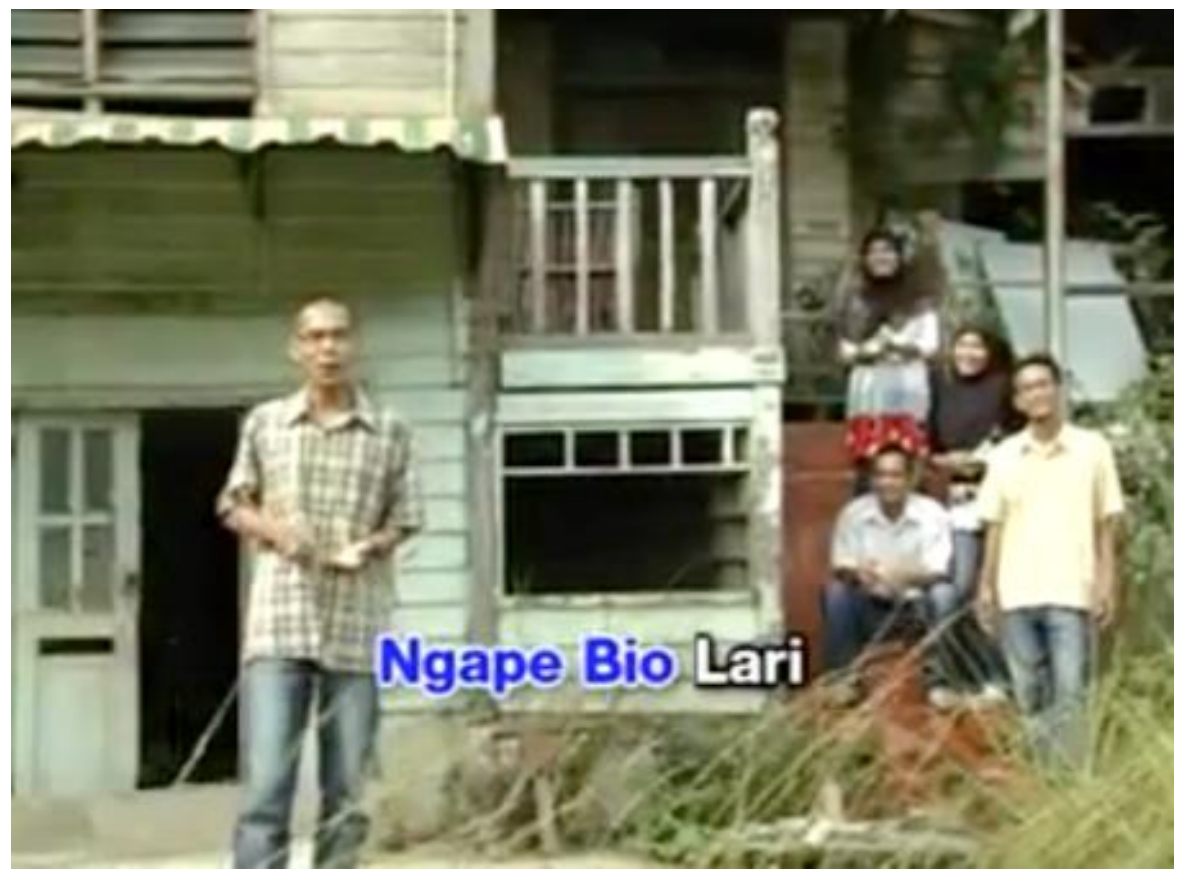

Figure 4: A screenshot of a music video of the song of Ngape Bio Semok with a background of abandoned old house

Pahang regional pop songs feature social criticism including unproductive behaviors, incompetent to manage family treasure due to lacking of education, loitering around without purpose and motor racing problem. As an example, the following transcription of the song Ngape Bio Semok (Why Letting the Bush Grows) represents demonstrative feelings towards lazy people. This song provides a useful advice for people to work hard to achieve their goals.

Ngape bio semok? (2x) / Why Letting the Bush Grows?

Tanah sekangkang kere ngape bio semok? $(2 x) /$ Why letting weeds to grow in a small land?

Ngape bio lari? $(2 x)$ / Why let the buffalo gone?

Kerbanye ande seko ngape bio lari? $(2 x)$ / There is only one buffalo but why has let gone?

Ngape mudoh lepe? Ngape mudoh ghalek? (2x) / Why being easy to be forgotten? Why being easy to be infatuated?

Kalanye ngendok senang kenela beringat-ingat, /If want to live happily so be mindful,

Kalanye ngendok menang kenela bekerje kuat, / If want to win so need to work hard,

Orang lepaih ke bulan awok dalam selimut, / People already reached the moon but you still in the blanket,

Orang naik kapeterebang awok tengesot-ngesot. / People are on a plane, but you are still crawling. 
Some lyrics contains values to cultivate and nurture towards a healthy life by providing Malay proverbs in the song, for instance, sikit-sikit lama-lama jadi bukit (little by little, in the end it becomes a hill), and berakit ke hulu berenang ke tepian biar sakit dulu asal senang kemudian (it is necessary to work hard in order to succeed). The account of historical context is also conveyed through the lyrics. For instance, the song Kole Semantan (River Mouth of Semantan) appraises the historic place of Kuala Semantan located at the confluence of two rivers, Semantan River and Pahang River. This song also features the historic Mount Senyum, a popular limestone mountain with folk stories and myth. In brief, there are various symbols/elements of traditional and modern represented in regional pop songs as cultural expressions to recognize the Pahang dialect spoken community. Symbols in music, to quote Wolvers, "may have a certain cultural connotation which is familiar to those who share a specific group identity" (Wolvers, 2010, p.12).

Does Pahang regional pop songs available on the popular social media of YouTube reflect the emergence of online social structure? Some examples of the emergence of community on the Internet are represented by people participating in conversations on YouTube, one of the most popular video sites. It is important to understand the relationship of online music user community with Pahang regional pop songs in the terrain of digital technology. Music ranks the highest among categories visited on YouTube. It is a focal music platform that provides social spaces and cultural resources for affiliation. People primarily used YouTube to look up artists, videos, and live music events. YouTube, no doubt, plays a significant part in the experience of the contemporary music listeners.

My examination on YouTube shows that all the twelve songs from Anok Semantan's first VCD music album have been uploaded on this video-sharing website. Those videos were professionally made and there was typically no embedded information. Interestingly, the producer or singers do not upload Pahang regional pop songs from VCDs, instead, by fans (user-uploaded copies). Pahang regional pop songs were uploaded to the website as early as 2010, a year after the first album was released in 2009 . The number of viewers ranges from thousands to hundreds of thousands, showing that interest for Pahang regional pop songs is relatively high. The following paragraphs provide how online Pahang regional pop music is used and discussed in specific contexts.

Aiman, an online music user from Pahang shared with me that YouTube is a continent for him (Aiman, personal communication, 23rd January 2019). If he wants to listen to Anok Semantan's songs, he would directly search on YouTube facilitated by mobile digital technologies, primarily mobile phones. This is in line with the view by Hartley that "the site has been seen an archive" (Hartley, 2012, p.165) with Vernalis even calling it "an archive without a librarian" (Vernalis, 2013, p.152). In addition, online music use encourages communicative activities around music. While listening to songs on YouTube, Aiman in the previous remarks explained that he would participate in sharing, communicating, and commenting about Pahang regional pop music with other online music users.

Pahang regional pop music on the site opens participation of online music users. They participate in dialogues and share mutual feeling towards songs. It is likely that online music users are of the Pahang people and/or have cultural relations with Pahang. Commenting on the song of Makwe Koi (My Girlfriend) (see https://www.youtube.com/watch?v=BJdUqjuFim8; accessed on 20th February 2019) one viewer says that she missed her village in Pahang. Other viewer left a comment that how lucky he is to find this song on YouTube. These comments inspired by listening to the song 
suggest that the capability of the song to bring back their mind to the village in Pahang as well as evoke nostalgic and good memories of the past.

I refer to an online conversation between Mohamad Azmi and Mohamed Ibrahim in regards with the song of Ngape Bio Semak (Why Letting the Bush Grows) (see https://www.youtube.com/watch?v=gbTIcM1km3c; accessed on 20th February 2019). Both of them have a similar characteristic - they are married to Pahang women. Through marriage, they have learned about Pahang regional pop songs, subsequently became fans of the music. Inspired by listening to the same song on YouTube, Emma Salleh (from Sarawak in northwest Borneo Island) and Amir Daniel (from the southern of Johor) have agreed that Pahang regional pop songs play an important role in introducing the Pahang dialect to the community. It is evidence that regional pop on YouTube is potential to induce online music users to learn more about the culture of Pahang people. Some viewers have thoughts that Pahang dialect in regional pop songs identical to several dialects of other regions. Reza has left his comment on the song Gone Gamoknye (How About It) (see https://www.youtube.com/watch?v=pulWUHTeMQQ; accessed on 26th February 2019) by saying that Pahang dialect is quite identical to a spoken language in Padang, West Sumatra, Indonesia. Mizi left her comments on the music video Kole Semantan (River Mouth of Semantan) and classified the Pahang dialect is identical to Perak dialect (see https://www.youtube.com/watch?v=5XSi33fHOLY\&index=4\&list=PLzzWVdeyJ6s8I6LMY1Q6 80-XPTO6oQUhS; accessed on 26th February 2019). Virtual community described the songs as simple and understandable. They listen to the songs while driving a car as well as doing their work. As demonstrated here, the availability of Pahang regional pop songs on the music web of YouTube has transformed listening modes (from offline to online music listening) as well as re-created meanings in community. The shift has provided online users to communicate with likeminded and contrasting individuals around the songs where conversation meld together and cannot easily be separated.

Besides uploading original, "authentic" music videos from Anok Semantan's VCD, some fans engage with different types of videos. First, they reproduced clips of music videos. They retained the original audio content but video content included user-created elements. Second, I found still videos that discarded the motion picture and replaced it either a still photo. Third, lyrics videos that resembled still videos, but visual content included song lyrics rolling with the music that similar to karaoke videos. Odexers, for instance, recreated 'alternative' music video of the song of Ngape Bio Semok with lyrics provided to invite music users to sing along or even rated and commented on the video.

The fourth and fifth types of videos are that of amateur recording videos of live performance of Anok Semantan in concert and videos of cover versions, respectively. I could see that different types of videos invited attention from users, however, elicit different engagement patterns. Original videos of Pahang regional pop songs received more views, votes and comments than the lyrics or still videos. It is probably because when users feel a need to discuss about a song, they are likely to share their opinion in the context of the "authentic" music videos. To conclude, YouTube has been seen as a participatory site. In relation to online music use, participatory culture can be used for describing fan community activities. Pahang regional pop music videos on YouTube have hundreds of thousands of viewers. Participators engage with each other within three public traces of interacting with music videos: viewing, commenting, and voting. The commentary field offers space for 
qualitative taste judgments and discussions often concern the artists, video, and music. It can also go off-topic and addresses different issues.

\section{CONCLUSION}

This paper has shown the formation of community around each music genre. The continuity of syair community after the concert could be seen when they involved in a communicative forum on Facebook. Meanwhile, YouTube has been a participatory site among fans of regional pop songs. They engage with each other within three public traces of interacting with music videos: viewing, commenting, and voting. The commentary field on YouTube offers a space for qualitative taste judgments and discussions often concern with singers, videos, and music. They can also go off-topic and address different issues. The results expose different in attitudes, motivations and practices between traditional and regional pop community.

\section{ACKNOWLEDGEMENT}

I would like to thank my supervisors, Prof. Dr. Bernard Arps and Dr. Suryadi Sunuri from Leiden University Institute for Area Studies in the Netherlands for their help and support. I am also grateful to all of the volunteers/informants who involved in this study, and to Madam Norlela Ismail from University Teknologi MARA (UiTM), Malaysia for her thoughts on this paper.

\section{BIODATA}

Shafa'atussara Silahudin is PhD researcher within Leiden University Institute for Area Studies (LIAS) in the Netherlands. Her PhD dissertation concerns with Malay singing and music performance in Pahang. Email: syafasara@um.edu.my/ syafasara@yahoo.com.my 


\section{REFERENCES}

Aiman. (2019, January 23). Personal communication (Interview).

Aripin Said. (1997). Lagu-lagu tradisional rakyat Pahang. Kuala Lumpur: Kementerian Kebudayaan, Kesenian dan Pelancongan Malaysia.

Aripin Said. (2004). Nyanyian rakyat khazanah bangsa yang hilang. Kuala Lumpur: Kementerian Kebudayaan, Kesenian dan Warisan Malaysia.

Asmah Omar. (1976). The phonological diversity of the Malay dialects. Kuala Lumpur: Dewan Bahasa dan Pustaka.

Aveling, Henry (ed.). (2002). Traditional Malay literature Second Edition. Kuala Lumpur: Dewan Bahasa dan Pustaka.

Brakeley, T. C. (1949). Work song: Standard dictionary of folklore, mythology and legend. New York: Annals of the New York Academy of Science.

Campbell, R., Martin, C. R., \& Fabos, B. (2007). Media \& culture: An introduction to mass communication. Boston: Bedford/St. Martin's.

Meddegoda, C. P. (2016). Appropriation of Hindustani musical elements in vocal parts of Malay ghazal. Malaysian Journal of Performing and Visual Arts, 2, 43-69.

Collins, J. T. (1989). Malay dialect research in Malaysia: the issue of perspective. Bijdragen tot de Taal-, Land- en Volkenkunde, 145(2/3), 235-264.

Ding, Y., Du, Y., Hu, Y., Liu, Z., Wang, L., Ross, K., \& Ghose, A. (2011). Broadcast yourself: understanding YouTube uploaders. In P. Thiran \& W. Willinger (Eds.), Proceedings of the 2011 ACM SIGCOMM conference on Internet measurement conference (IMC'11), pp. 361-370. New York: ACM Press.

Ejjalz Syah (username). (n. d.). Gone Gamoknye - Anok Semantan. YouTube. Retrieved from https://www.youtube.com/watch?v=pulWUHTeMQQ

Ejjalz Syah (username). (n. d.). Kole Semantan - Anok Semantan. YouTube. Retrieved from https://www.youtube.com/watch?v=5XSi33fHOLY\&index=4\&list=PLzzWVdeyJ6s816 MY1Q680-XPTO6oQUhS

Ejjalz Syah (username). (n. d.). Makwe Koi - Anok Semantan. YouTube. Retrieved from https://www.youtube.com/watch?v=BJdUqjuFim8

Ejjalz Syah (username). (n. d.). Ngape Bio Semok - Anok Semantan. YouTube. Retrieved from https://www.youtube.com/watch?v=gbTIcM1km3c

Facebook Statistic. (2016). Social media statistics. Retrieved from https://smallbiztrends.com/2016/11/social-media-statistics-2016.html

Fadlina. (2016, June 2). Personal communication (Interview).

Hartley, J. (2012). Digital futures for cultural and media studies. Chichester: Wiley-Blackwell. Junaidi Kassim. (2019, January 23). Personal communication (Interview).

Nik Safiah Karim, Farid M. Onn, Hashim Haji Musa. (1986). Tatabahasa dewan 1. Kuala Lumpur: Dewan Bahasa dan Pustaka.

Kosinski, M., Stillwell, D., \& Graepel, T. (2013). Private traits and attributes are predictable from digital records of human behavior. Proceedings of the National Academy of Sciences of the United States of America, 110, 5802-5805.

Liikkanen, L. A., \& Salovaara, A. (2015). Music on YouTube: User engagement with traditional, user-appropriated and derivative videos. Computers in Human Behavior, 50, 108-124.

Malm, K., \& Wallis, R. (1984). Big sounds from small peoples: The music industry in small countries. London: Constable. 
Maros, M. 2010. Dialek Melayu Pekan: Penggunaan dan pengekalan. Jurnal Bahasa, 10(1), 74-97.

Matusky, P. (1985). An introduction to the major instruments and forms of traditional Malay music. Asian Music 6(2, Spring - Summer), 121-182.

Pejabat Kebudayaan dan Kesenian Negeri Pahang. (2003). Koleksi pengenalan tarian \& muzik tradisional Negeri Pahang. Kuantan: Pengarang.

Proehoeman, S. C. (2012). Lyrics diction of Indonesian and Malay art songs for singer. The International Journal of Arts, Culture and Heritage, 1, 101-123.

Top Sites in Malaysia. (n. d.). Alexa.com. Retrieved from https://www.alexa.com/topsites/countries/MY

Vernalis, C. (2013). Unruly media: YouTube, music video and the new digital cinema. Oxford: Oxford University Press.

Wallach, J. (2008). Modern noise, fluid genres: Popular music in Indonesia, 1997-2001. Madison: University of Wisconsin Press.

Wolvers, A. (2010). Sounds of resistance: African identity in Jamaican music from a postcolonial perspective. Saarbrücken: VDM Verlag Dr. Müller.

Yu, H., \& Schroeder, S. (2018). Distribution and popularity patterns of Chinese music on YouTube: A case study on local music's representation on a global Internet platform. Journal of New Music Research, 47(1), 68-77. 